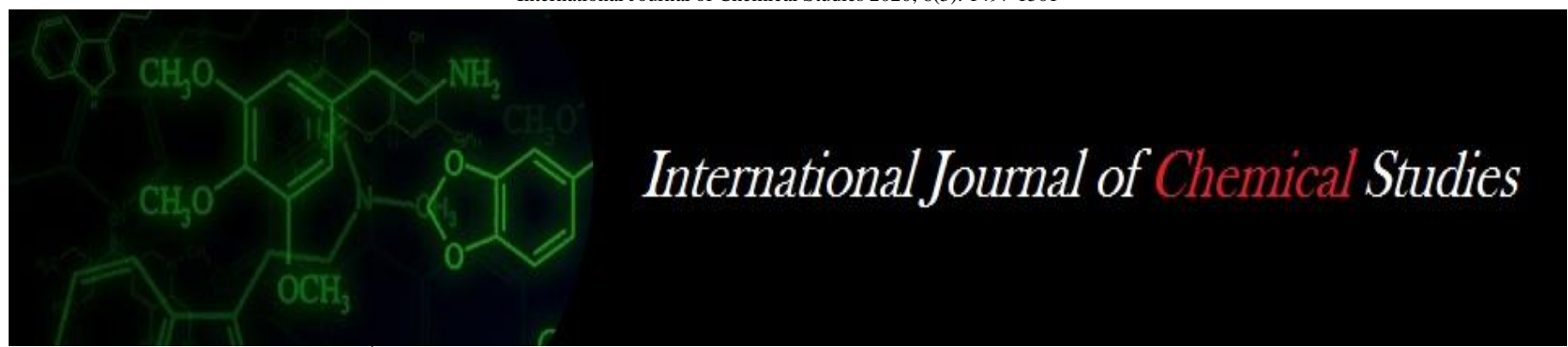

P-ISSN: 2349-8528

E-ISSN: 2321-4902

www.chemijournal.com

IJCS 2020; 8(3): 1497-1501

(C) 2020 IJCS

Received: 24-03-2020

Accepted: 25-04-2020

Jayashree Bambalwad

Department of Plant Pathology,

College of Agriculture, V. C.

Farm, Mandya, Karnataka,

India

Pankaja NS

Asst. Prof. of Plant Pathology,

College of Agriculture, V. C.

Farm, Mandya, Karnataka,

India

Sugeetha G

Asst. Prof. of Agricultural

Entomology, College of

Agriculture, V. C. Farm,

Mandya, Karnataka, India

Mahadev J

Asst. Prof. of Forestry and Environmental Sciences, College of Agriculture, V. C. Farm,

Mandya, Karnataka, India

\section{Benherlal PS}

Asst. Prof. of Biochemistry,

Biotechnology Division, GKVK,

Bangalore, Karnataka, India
Corresponding Author: Jayashree Bambalwad

Department of Plant Pathology,

College of Agriculture, V. C.

Farm, Mandya, Karnataka,

India

\section{Influence of synthetic and natural fungicides, environmental and physiological factors on the uredospore germination of the pathogen causing rust disease in cowpea}

\author{
Jayashree Bambalwad, Pankaja NS, Sugeetha G, Mahadev J and \\ Benherlal PS
}

DOI: https://doi.org/10.22271/chemi.2020.v8.i3t.9407

\begin{abstract}
Cowpea (Vigna unguiculata (L.) Walp.) Is one of the most important pulse crops in Karnataka. Rust disease caused by Uromyces phaseoli var. vignae (Barclay) Arthur is a major threat for its cultivation causing severe yield loss. Among the six fungicides and ten botanicals, maximum per cent inhibition of germination of uredospores was observed at $50 \mathrm{ppm}$ in propiconazole $25 \% \mathrm{EC}(78.87 \%)$, followed by hexaconazole $5 \%$ EC $(77.37 \%)$. Whereas, least per cent inhibition of uredospores germination was recorded in treatment with tebuconazole $25 \% \mathrm{EC}$ at $10 \mathrm{ppm}(67.17 \%)$ followed by difenconazole $25 \% \mathrm{EC}$ (75.70\%). Among different botanicals neem extract at $7.5 \%$ showed highest inhibition of $68.06 \%$, however, ginger extract at $2.5 \%$ recorded least uredospore germination of $26.10 \%$. Inorder to know optimum temperature and relative humidity for Uredininospore germination, an experiment was conducted under at temperature between $5-35^{\circ} \mathrm{C}$ and relative humidity regimes ranging between $0-100 \%$. The maximum per cent of uredopsores germination $(80.50 \%)$ was recorded at $20^{\circ} \mathrm{C}$. however germination did not occur at $0^{\circ} \mathrm{C}$ and $35^{\circ} \mathrm{C}$. When the relative humidity was 100 per cent the per cent germination of uredospores was 83.67 per cent which was maximum. No germination occured at zero per cent relative humidity. Different nitrogen and Carbon sources were tested at three different concentrations to study the influence of physiological factors on uredinospore germination. Highest germination was recorded in sucrose at $1.5 \%(36.10 \%)$, whereas in case of $0.5 \%$ mannitol least germination $\left(15.60 \%\right.$ ) was obtained. Among the nitrogen sources $\mathrm{KNO}_{3}$ at $1.5 \%$ concentration showed maximum germination of $68.07 \%$, least germination was recorded in $\mathrm{NaNO}_{3}$ at $0.5 \%$ with $18.07 \%$ germination.
\end{abstract}

Keywords: Rust disease, uredospore, germination, fungicides, botanicals

\section{Introduction}

Cowpea (Vigna unguiculata) is an annual herbaceous legume from the genus Vigna. It is adapted to wide ranges of soil and rainfall situations, hence, cultivated in tropical and subtropical regions of the world. It is grown throughout India and is well suited to dryland agriculture. It is a popular crop due to its rich sources of high-quality protein of about 24.8 per cent, 1.8 per cent fat and 60.3 per cent carbohydrates. (Ddamulira, G., and Santos, C. 2015) ${ }^{[6]}$. In addition to protein, the edible leaves and seeds of legumes also contain high levels of dietarily-important mineral nutrients, which are needed for human nutrition and health, especially for overcoming trace element deficiency and promoting brain development. The mineral concentrations are reported to be $142-626$ and $60-99 \mathrm{mg}^{-\mathrm{kg}^{-1}}$ for Fe, 49-104 and 4465 mg.kg ${ }^{-1} \mathrm{Zn}, 196-394$ and 5-32 mg.kg ${ }^{-1} \mathrm{Mn}, 8.6-19.7$ and 8.3-14.7 mg.kg ${ }^{-1} \mathrm{Cu}$ and 42-55 and $10-22 \mathrm{mg} \cdot \mathrm{kg}^{-1} \mathrm{~B}$ in cowpea leaves and seeds, respectively (Belane and Dakora, 2011) ${ }^{[2]}$. However, cowpea production is suppressed by several pests and diseases. Among them, cowpea rust infections caused by Uromyces phaseoli var. vignae are the most severe and devastating [M. Chandrashekar, et al., 1989 ${ }^{[4]}$.

Rust can appear on any part of the cowpea plant above ground and spreads rapidly to the middle and upper parts of the host especially during pod formation. Cowpea rust interferes with normal root development and uptake of nutrients by plant roots, resulting in reduced seed size and considerable yield loss (PAN 2014) ${ }^{[13]}$. 
Uredospores of most rust fungi (e.g. Uromyces, Puccinia, Melampsora) germinate and grow, directed by the leaf surface toward stomata where they cease growth and develop appressoria directly over the stomatal openings. Subsequently, an infection peg grows from the appressorium on the side adjacent to the leaf surface and penetrates the stomatal aperture (Staples et al., 1985, Wynn 1976) ${ }^{[16,18]}$ thus forming a very important infection structure in causing disease.

About 2,000 urediniospores of the pathogen are released per day during the dry season [BSPP, 2017] [3]. At the present, there is no single cost-efficient control measure to prevent rust infection particularly in different geographical areas [Souza et al., 2013] ${ }^{[15]}$. However, Production and germination of propagules and pathogen growth rates are strongly dependent on temperature, relative humidity (RH), and, in the case of foliar pathogens, often leaf wetness (Colhoun 1973; Huber and Gillespie 1992) ${ }^{[5,8]}$.

Since spore germination is fundamentally important to the growth and dissemination of most fungi. Fungal spores require nutrients to be present in their environment for germination to occur and for outgrowth into hyphae (AbdelRahim AM, Arbab HA. 1985) [1]. Nitrogen metabolism is required for the synthesis of nucleic acids and proteins, processes that are known to occur early during the course of conidial germination (Osherov N, May GS. 2001 and Taubitz A, Bauer B, Heesemann J, Ebel F. 2007) ${ }^{[12,17]}$.

Keeping all these points in view an experiment was designed to know the influence of various external factors on the germination of uredospores.

\section{Materials and Methods}

The uredospores were collected from a susceptible variety $\mathrm{C}$ 152 by scrapping the surface of uredia with a pre sterilized scalpel.

\section{In-vitro evaluation of fungicides and botanicals against the pathogen}

Six different fungicides (Table 1), ten plant species (Table 2) were tested for its efficacy on uredospore germination at 10 , 25 and 50 ppm.and 2.5, 5 and $7.5 \%$ concentrations respectively. The botanical extract was prepared by crushing the plant parts with distilled water in $1: 1 \mathrm{w} / \mathrm{v}$ one drop of fungicide/botanical solution was mixed with a drop of spore suspension in a cavity slide. Each treatment was replicated thrice. The number of spores germinated were observed at 24 hour after incubation under the microscope at $40 \mathrm{X}$ magnification. Per cent inhibition of uredospore germination was calculated by using the following formula given by Vincent (1947).

$\mathrm{PI}=\frac{\mathrm{C}-\mathrm{T}}{\mathrm{C}} \times 100$

Where,

$\mathrm{PI}=$ Per cent inhibition of spore germination

$\mathrm{C}=$ Germination of spores in control

$\mathrm{T}=$ Germination of spores in treatment

\section{Studies on effect of temperature and relative humidity on} germination of uredospores

Two drops of uredospore suspension were placed on clean glass cavity slides and then they were incubated at different temperature regimes (Table 3). Similar experiment was conducted at different $\mathrm{RH}$ regimes (Table 4). The per cent germination of uredospores was recorded after $24 \mathrm{hr}$ of incubation.

\section{Studies on effect of different carbon and nitrogen sources} on germination of uredospores

The carbon sources viz., sucrose, starch, dextrose, maltose, fructose and mannitol at three different concentrations $(0.5 \%$, $0.1 \%$ and $1.5 \%$ ), nitrogen sources viz., potassium nitrate $\left(\mathrm{KNO}_{3}\right)$, peptone, sodium nitrate $\left(\mathrm{NaNO}_{3}\right)$, ammonium sulphate $\left(\mathrm{NH}_{4} \mathrm{SO}^{4}\right)$, ammonium nitrate $\left(\mathrm{NH}_{4} \mathrm{NO}_{3}\right)$ and ammonium chloride $\left(\mathrm{NH}_{4} \mathrm{Cl}\right)$ were evaluated at 3 different concentrations $(0.5 \%, 0.1 \%$ and $1.5 \%)$ on the germination of uredospores. Then 2 drops of spore suspension were mixed with different concentrations of carbon and nitrogen sources on cavity slides separately. After $24 \mathrm{hr}$. of incubation the per cent germination of uredospore was recorded.

\section{Results and discussion}

\section{Effect of fungicides and botanicals on the uredospore germination \\ Fungicides}

The above results revealed that all the fungicides tested exhibited maximum inhibition of uredospores germination at their highest concentration (50ppm) (Table 1). Thus among the six fungicides tested propiconazole $25 \%$ EC showed highest inhibition of germination of uredospores at 50ppm $(78.87 \%)$ followed by hexaconazole $5 \%$ EC at 50ppm $(77.37 \%)$ and mancozeb $75 \%$ WP $(76.57 \%)$ and the highest inhibition of germination of uredospores was recorded in tebuconazole $25 \% \mathrm{EC}(67.17 \%)$ at $10 \mathrm{ppm}$ followed by difenconazole $25 \% \mathrm{EC}(68.17 \%)$ at $10 \mathrm{ppm}$ and chlorothalonil $75 \%$ WP $(68.57 \%)$ at $10 \mathrm{ppm}$. The present results are in accordance with Kale (1996) ${ }^{[9]}$ in the chemical management of cowpea rust where he reported that triazoles like propiconazole, hexaconazole and chlothalonil were effective in inhibition of uredospores.

Table 1: Effect of fungicides on uredospore germination

\begin{tabular}{|c|c|c|c|}
\hline & \multicolumn{3}{|c|}{ Per cent reduction of spore germination } \\
\hline Fungicides & & Concentration (ppm) & \\
\hline & $\mathbf{1 0}$ & $\mathbf{2 5}$ & $\mathbf{5 0}$ \\
\hline Propiconazole (25\% EC) & 70.85 & 73.50 & 78.87 \\
\hline Hexaconazole (5\% EC) & 69.97 & 73.30 & 77.37 \\
\hline Tebuconazole (25\% EC) & 67.17 & 71.30 & 74.50 \\
\hline Chlorothalonil (75\% WP) & 68.57 & 72.17 & 76.37 \\
\hline Mancozeb (75\% WP) & 69.40 & 73.23 & 76.57 \\
\hline Difenconazole (25\% EC) & 68.17 & 71.37 & 75.70 \\
\hline & Fungicides (F) & Concentration (C) & F $\times$ C \\
\hline S. Em \pm & 0.15 & 0.11 & 0.26 \\
\hline CD (P=0.01) & 0.58 & 0.41 & 1.00 \\
\hline
\end{tabular}

\section{Botanicals}

Among ten botanicals evaluated the highest per cent inhibition of uredospores $(68.06 \%)$ was recorded in neem extract at $7.5 \%$ followed by tulsi at $7.5 \%$ with $64.40 \%$ of inhibition. The least per cent inhibition of uredospores was obtained in ginger extract $(42.33 \%)$ followed by turmeric extract $(44.13 \%)$. However ginger extract at $2.5 \%$ inhibited least uredospore germination of $26.10 \%$ followed by turmeric extract at $2.5 \%$ with $28.66 \%$ inhibition. The neem extract has significant effect in inhibition of uredospores germination compared to other botanicals (Table 2). The results are in accordance with Shabana et al. (2017) ${ }^{[14]}$ who studied the effect of botanicals on germination of uredospores of wheat leaf rust (Puccinia graminis tritici) and reported that neem 
was effective in inhibiting the spore germination of 68.99 per cent.

Table 2: Effect of differentbotanicalson uredospore germination

\begin{tabular}{|c|c|c|c|}
\hline & \multicolumn{3}{|c|}{ Per cent reduction of spore germination } \\
\hline Botanicals & & Concentration (\%) & \\
\hline & $\mathbf{2 . 5}$ & $\mathbf{5 . 0}$ & $\mathbf{7 . 5}$ \\
\hline Neem & 42.63 & 55.46 & 68.06 \\
\hline Garlic & 40.76 & 54.43 & 61.40 \\
\hline Onion & 37.80 & 53.23 & 61.33 \\
\hline Parthenium & 32.76 & 50.46 & 59.40 \\
\hline Marigold & 34.50 & 52.43 & 59.56 \\
\hline Pongamia & 31.80 & 47.46 & 57.80 \\
\hline Lantana & 35.36 & 52.96 & 59.70 \\
\hline Turmeric & 28.66 & 46.00 & 57.73 \\
\hline Ginger & 26.10 & 43.36 & 57.53 \\
\hline Tulsi & 41.23 & 54.56 & 64.40 \\
\hline & Botanicals (B) & Concentration $(\mathrm{C})$ & $\mathrm{B} \times \mathrm{C}$ \\
\hline S. Em \pm & 0.29 & 0.16 & 0.51 \\
\hline CD $(\mathrm{P}=0.01)$ & 1.10 & 0.60 & 1.92 \\
\hline
\end{tabular}

Effect of temperature and relative humidity on the uredospore germination

Temperature

The per cent germination of uredospores at different temperatures varied significantly. The results of the experiment are presented in Table 3 . In the present study, it is clear that a good germination of uredospores was observed at temperature between $18-24^{\circ} \mathrm{C}$. However, at $20^{\circ} \mathrm{C}$ temperature maximum per cent of uredopsores germination $(80.50 \%)$ was recorded followed by $22^{\circ} \mathrm{C}(73.66 \%)$ and there was also a significant difference between them. At $18^{\circ} \mathrm{C}$ there was germination of $71.00 \%$ and at $24^{\circ} \mathrm{C}$ it was 66.40 per cent with significant difference between them. However, there was no germination at 0 and $35^{\circ} \mathrm{C}$. In other temperatures regimes like $5,10,15,26,28$ and $30^{\circ} \mathrm{C}$ the uredospores germination of 3.0 , $15,32,37.23,30.33$ and 8.33 per cent was recorded respectively. The present results are in accordance with Mohamed et al., (1986) ${ }^{[11]}$ who studied on the germination of uredospores of bean rust caused by Uromyces viciae-fabae and reported that temperature below 10 and above $40{ }^{\circ} \mathrm{C}$ did not favour the germination of urdospores. Similarly, Emeran et al., (2005) ${ }^{[7]}$ also found that temperature of $20^{\circ} \mathrm{C}$ is more favourable for germination of uredospores on legume (Uromyces viciae- fabae). Thus, it can be concluded the temperature range for germination of uredospores was found to be between 18 to $24^{\circ} \mathrm{C}$.

Table 3: Effect of temperature levels on germination of uredospores

\begin{tabular}{|c|c|c|c|}
\hline S. No. & Temperature $\left({ }^{\circ} \mathbf{C}\right)$ & \multicolumn{2}{|c|}{ Per cent germination } \\
\hline 1. & 0 & 0.00 & $(0.34)$ \\
\hline 2. & 5 & 3.00 & $(9.98)$ \\
\hline 3. & 10 & 15.00 & $(22.79)$ \\
\hline 4. & 15 & 32.00 & $(34.45)$ \\
\hline 5. & 18 & 71.00 & $(57.42)$ \\
\hline 6. & 20 & 80.50 & $(63.80)$ \\
\hline 7. & 22 & 73.66 & $(59.13)$ \\
\hline 8. & 24 & 66.40 & $(54.58)$ \\
\hline 9. & 26 & 37.23 & $(37.61)$ \\
\hline 10. & 28 & 30.33 & $(33.42)$ \\
\hline 11. & 30 & \multicolumn{2}{|c|}{$8.33(16.78)$} \\
\hline 12. & 35 & 0.00 & $(0.34)$ \\
\hline & S. Em \pm & \multicolumn{2}{|c|}{0.69} \\
\hline & CD $(\mathrm{P}=0.01)$ & \multicolumn{2}{|c|}{2.75} \\
\hline
\end{tabular}

Note: Figures in parenthesis are arcsine values

\section{Relative humidity}

The data (Table 4) revealed that maximum uredospores germination was observed at 100 per cent $\mathrm{RH}(83.67 \%)$ followed by 90 per cent $(77.16 \%), 80$ per cent $(72.00 \%), 70$ per cent $(64.87 \%)$ and at 60 per cent $(41.00 \%)$ and there was a significant difference among them. The least per cent germination was recorded in 0 per cent $\mathrm{RH}(0.00 \%)$ followed by 10 per cent $(5.16 \%)$ with a significant difference between them. From the above results it can be revealed that, there was increase in per cent germination with the increase in relative humidity. Similar results were obtained by Mohamed et al. (1986) [11] who reported highest per cent germination of uredospores of bean rust caused by Uromyces appendiculatus at 95 to 100 per cent relative humidity.

Table 4: Effect of relative humidity levels on germination of uredospores

\begin{tabular}{|c|c|c|}
\hline S. No. & Relative humidity $\mathbf{( \% )}$ & Per cent germination \\
\hline 1. & 0 & $0.00(0.34)$ \\
\hline 2. & 10 & $5.16(13.13)$ \\
\hline 3. & 20 & $6.43(14.69)$ \\
\hline 4. & 30 & $21.60(27.70)$ \\
\hline 5. & 40 & $26.03(30.68)$ \\
\hline 6. & 50 & $28.33(32.16)$ \\
\hline 7. & 60 & $41.00(39.82)$ \\
\hline 8. & 70 & $64.87(53.66)$ \\
\hline 9. & 80 & $72.00(58.06)$ \\
\hline 10. & 90 & $77.16(61.46)$ \\
\hline 11. & 100 & $83.67(66.17)$ \\
\hline & $\mathrm{S} . \mathrm{Em} \pm$ & 0.681 \\
\hline & $\mathrm{CD}(\mathrm{P}=0.01)$ & 2.71 \\
\hline
\end{tabular}

Note: Figures in parenthesis are arcsine values

Effect of different carbon and nitrogen sources on germination of uredospores

From the study, it was observed that there was a significant difference in the uredospore germination among the different concentrations of carbon sources tested.

\section{Carbon}

The results indicate that among the six carbon sources the highest average germination of uredospores was recorded in sucrose at $1.5 \%(36.10 \%)$ followed by starch at $1.5 \%$ $(32.87 \%)$ and there was a significant difference between them and the least average germination of uredospores was recorded in mannitol at $0.5 \%(15.60 \%)$ followed by fructose $0.5 \%(16.87 \%)$ and maltose $0.5 \%(18.13 \%)$ (Table 5). These finding are in accordance with Khedekar (2012) where he reported that maximum spore germination of 77.30 to $83.03 \%$ 
in two per cent sucrose solution. This indicates that $U$. phaseoli var.vignae is a sugar loving fungus and it requires sugar for its germination and infection on the host.

Table 5: Effect of different carbon sources on germination of uredospores

\begin{tabular}{|c|c|c|c|c|}
\hline S. No. & Carbon sources & Per cent germination of uredospores Concentration (\%) & \\
\hline & & $\mathbf{0 . 5}$ & $\mathbf{1 . 0}$ & $\mathbf{1 . 5}$ \\
\hline 1. & Sucrose & 20.33 & 26.50 & 36.10 \\
\hline 2. & Starch & 19.77 & 25.20 & 32.87 \\
\hline 3. & Dextrose & 18.30 & 25.03 & 30.70 \\
\hline 4. & Maltose & 18.13 & 23.40 & 29.40 \\
\hline 5. & Fructose & 16.87 & 21.90 & 28.30 \\
\hline 6. & Mannitol & 15.60 & 20.88 & 28.10 \\
\hline & Carbon sources & Concentration & Cs $\times$ C & Carbon sources \\
\hline & $(\mathrm{Cs})$ & $(\mathrm{C})$ & & $(\mathrm{Cs})$ \\
\hline $\mathrm{S} . \mathrm{Em} \pm$ & 0.33 & 0.24 & 0.58 & 0.33 \\
\hline $\mathrm{CD}(\mathrm{P}=0.01)$ & 1.28 & 0.91 & 2.22 & 1.28 \\
\hline
\end{tabular}

\section{Nitrogen}

Similarly it was observed that, among the six nitrogen sources the highest average germination of uredospores was recorded in potassium nitrate at $1.5 \%(68.07 \%)$ followed by ammonium nitrate at $1.5 \%(65.77 \%)$ and ammonium chloride at $1.5 \%(64.17 \%)$ and the least average germination of uredospores was recorded in sodium nitrate at $0.5 \%(18.07 \%)$ followed by peptone $0.5 \%(21.33 \%)$ and ammonium sulphate $0.5 \%(23.17 \%)$.

Table 6: Effect of different nitrogen sources on germination of uredospores

\begin{tabular}{|c|c|c|c|c|}
\hline S. No. & Nitrogen sources & Per cent germination of uredospores Concentration (\%) & \\
\hline & & $\mathbf{0 . 5}$ & $\mathbf{1 . 0}$ & $\mathbf{1 . 5}$ \\
\hline 1. & $\mathrm{KNO}_{3}$ (Potassium nitrate) & 29.83 & 51.57 & 68.07 \\
\hline 2. & Peptone & 21.33 & 34.17 & 57.60 \\
\hline 3. & $\mathrm{NaNO}_{3}$ (Sodium nitrate) & 18.07 & 33.77 & 55.90 \\
\hline 4. & $\mathrm{NH}_{4} \mathrm{SO}_{4}$ (Ammonium sulphate) & 23.17 & 37.50 & 59.57 \\
\hline 5. & $\mathrm{NH}_{4} \mathrm{NO}_{3}$ (Ammonium nitrate) & 29.47 & 48.60 & 65.77 \\
\hline 6. & $\mathrm{NH}_{4} \mathrm{Cl}$ (Ammonium chloride) & 25.90 & 45.53 & 64.17 \\
\hline & Nitrogen sources(N) & Concentration $(\mathrm{C})$ & $\mathrm{N} \times \mathrm{C}$ & Nitrogen sources(N) \\
\hline $\mathrm{S} . \mathrm{Em} \pm$ & 0.34 & 0.24 & 0.60 & 0.34 \\
\hline $\mathrm{CD}(\mathrm{P}=0.01)$ & 1.33 & 0.94 & 2.30 & 1.33 \\
\hline
\end{tabular}

\section{Conclusion}

In the present investigation, effects of different parameters viz, temperature, relative humidity, fungicides, botanicals, carbon and nitrogen source were evaluated invitro for the germination of uredospore of cowpea rust pathogen. The fungicide propiconazole $25 \% \mathrm{EC}$ was able to inhibit the germination of the spore at 50ppm $(78.87 \%)$. The next best fungicide observed was hexaconazole $5 \% \mathrm{EC}$ which recorded $77.3 \%$ inhibition at $50 \mathrm{ppm}$. Whereas, the germination of uredospores was inhibited to a maximum extent by neem extract $(68.06 \%)$ among the botanicals tested. Temperature and relative humidity has a greater influence on the germination of the uredopsores. In this study it was observed at the temperature $20^{\circ} \mathrm{C}$ and relative humidity of $100 \%$ there was a maximum number uredospore germination $(80.50 \%$ and $83.67 \%$, respectively). Further, The carbon source sucrose at $1.5 \%$ and nitrogen source KNO3 at $1.5 \%$ exhibited maximum uredospore germination of $36.10 \%$ and $68.07 \%$, respectively.

\section{References}

1. Abdel-Rahim AM, Arbab HA. Nutrient requirements in germination of conidiospores of Aspergillus niger $\mathrm{V}$. Tieghen. Mycopathologia. 1985; 92:111-113.

2. Belane AK, Dakora FD. Levels of nutritionally-important trace elements and macronutrients in edible leaves and seed of 27 nodulated cowpea (Vigna unguiculata L. Walp.) genotypes grown in the Upper West Region of Ghana. Food Chem. 2011; 125:99-105.
3. BSPP. Bean Rust Fungus, 2017. https://www.bspp.org.uk/downloads/.../BSPP_Bean_Rust _Inf o.pdf.

4. Chandrashekar M, Kumar Anil TB, Saifulla M, Yadahally YH. Effect of different dates of sowing cowpea on the severity of leaf rust caused by Uromyces phaseoli var. vignae, Tropical agriculture. 1989; 66(2):149-152.

5. Colhoun J. Effects of environmental factors on plant disease. Annu. Rev. Phytopathol. 1973; 11:343-364.

6. Ddamulira G, Santos C. Grain yield and protein content of Brazilian cowpea genotypes under diverse Ugandan environments. Am. J Plant Sci. 2015; 6:2074.

7. Emeran AA, Sillero JC, Fernandez MA, Rubiales D. Influence of temperature on germination of uredospores of Uromyces viciaefabae. Tech. Bulletin Kagawaken Agric. Coll. 2005; 3:15-18.

8. Huber L, Gillespie TJ. Modeling leaf wetness in relation to plant disease epidemiology. Annu. Rev. Phytopathol. 1992; 30:553-577.

9. Kale JK, Anahosur KH. Chemical controls of cowpea rust. Kar. J Agric. Sci. 1996; 9(1):179-181

10. Khedekar SA. Studies on soyabean rust (Phakopsora pachyrhizi Syd.) and chickpea rust (Uromyces cicerisarietini (Grognot) Jacz. and Boy). PhD thesis. Univ. Agric. Sci. Dharwad, Karnataka, India, 2012.

11. Mohamed HA, Abdel-AL HR, Fadl FA, Shatta HM, Nagi IM. Reaction of bean cultivars to rust and its relation to stomatal size. Egyptian J. Phytopathol. 1986; 15:1-6. 
12. Osherov N, May GS. The molecular mechanisms of conidial germination. FEMS Microbiol. Lett. 2001; 199:153-160.

13. PAN. Field guide to non-chemical pest management in cowpea. Hamburg, Germany: Pesticide Action Network, 2014, 16.

14. Shabana YM, Abdalla MA, Shahin AA, El-Sawy MM, Draz IS, Youssif AW. Efficacy of plant extracts in controlling wheat leaf rust disease caused by Puccinia triticina. Egyptian J Basic Appl. Sci. 2017; 4:67-73.

15. Souza TLPO, Faleiro FG, Dessaune SNDE, Paula-Junior TJ, Moreira MA. Breeding for common bean (Phaseolus vulgaris L.) rust resistance in Brazil, Tropical Plant Pathology. 2013; 38(5):361-374.

16. Staples RC, Hoch HC, Epstein L, Laccetti L, Hassouna S. Recognition of host morphology by rust fungi: responses and mechanisms. Can. J Plant Pathol. 1985; 7:314-22.

17. Taubitz A, Bauer B, Heesemann J, Ebel F. Role of respiration in the germination process of the pathogenic mold Aspergillus fumigatus. Curr. Microbiol. 2007; 54:354-360.

18. Wynn WK. Appressorium formation over stomates by the bean rust fungus: Response to a surface contact stimulus. Phytopathology. 1976; 66:136-46. 